Birlesik Dünya Arastırma

BD-CENTER

Innovasyon ve Yayıneılık Merkezi
Global Journal of Guidance and Counseling in Schools: Current Perspectives
Global Journal of Guidance \& Counselling in Schools: Current Perspectives

Volume 9, Issue 3, (2019) 115-130

www.gigc.eu

\title{
The factors of compassion fatigue among guidance counsellors
}

\author{
Rhenan D. Estacio*, Centro Escolar University, Mendiola, Manila 1008, Philippines
}

\section{Suggested Citation:}

Estacio, R. D. (2019). The factors of compassion fatigue among guidance counsellors. Global Journal of Guidance and Counseling in Schools: Current Perspectives, 9(3), 115-130. https://doi.org/10.18844/gigc.v9i3.4343

Received from March 05, 2019; revised from July 05, 2019; accepted from December 02, 2019.

Selection and peer review under responsibility of Prof. Dr. Kobus Maree, University of Pretoria South Africa.

${ }^{\circ} 2019$ United World Center of Research Innovation and Publication. All rights reserved.

\begin{abstract}
The research was about the compassion fatigue and its contributing factors in guidance counsellors. The sample for the study was 92 guidance counsellors. This study explored factors of compassion fatigue, work-related factors, personality traits and demographic factors utilising the following instruments: professional quality of life scale (ProQOLs), NEO PI-R and demographic questionnaire. The context for the study was different schools in Central Luzon - Region 3, Philippines. Descriptive statistics and multiple regression stepwise method were utilised in the study. Findings indicated that participants had low levels of burnout and low levels of secondary trauma stress as elements of compassion fatigue. Personality traits of the participants identified include low levels of neuroticism, average levels of extraversion, average levels of openness to experience, high level of agreeableness and high levels of conscientiousness. Multiple regression stepwise method confirmed that the personality traits neuroticism, extraversion and agreeableness predict burnout with a variability of $40 \%$. Likewise, salary as work-related factor also predicts burnout with a variability of $4.7 \%$. Similarly, personality trait neuroticism is confirmed to predict secondary trauma stress with a variability of $21.9 \%$. Based on the two elements of compassion fatigue, neuroticism was found out to be the best predictor among the personality traits.
\end{abstract}

Keywords: burnout; compassion fatigue; guidance counsellors; secondary traumatic stress;

\footnotetext{
* ADDRESS FOR CORRESPONDENCE: Rhenan D. Estacio, Centro Escolar University, Mendiola, Manila 1008, Philippines.

E-mail address: $\underline{\text { nhanestacio@gmail.com }}$
} 


\section{Introduction}

Helping professionals are experts that nurture the growth of individuals, as well as address their physical, psychological, intellectual, emotional or spiritual well-being. They strive to help others to live better. These professionals deliver patient care by making a community safer and supporting programs that protect and rehabilitate vulnerable population (Maddock, 2018). Health care professionals include social service workers, teachers, attorneys, police officers, firefighters and clergy. Others are airline and other transportation staff, disaster site clean-up crews and professionals who offer assistance service to those in need (Stamm, 2010). Mental health practitioners are also considered as health care professionals. For instance, guidance counsellors are mental health professionals with a conjoint professional identity that encompasses knowledge and expertise in educational leadership and mental health to better respond to all students, including those with mental health needs (DeKruyf, Auger, \& Trice-Black, 2013).

One of the human development services is counselling. In the Philippines, it continues to struggle due to very opposing conditions and concerns. In addition, there are specific concerns and issues that the guidance counsellors encounter in which they are struggling (Abrenica, 2012). In the same manner, guidance counsellors' functions are mostly given the work of a discipline officer, which is a concern to them (Villar, 2007). Some concerns are tasks related that are not their function in relation to their work like checking of attendance and being assigned to serve as liaison officers (Abrenica, 2012). Furthermore, guidance counsellors take on new roles and develop new and competencies to make their impact felt by their different clientele (Abrenica, 2012). Regardless of issues and concerns, guidance counsellors are struggling to come across their mandate of multiple functions while trying to assume the role and perform the tasks of guidance and counselling (Paisley \& MacMahon, 2001).

Employees in the helping professions are often underpaid and since money equals value in the society, this communicates how little the society values the services these individuals provide (Stemen, 2014). The salary and remuneration among guidance counsellors become one of the significant issues and concerns for practitioners in the Philippines (Lagon, 2016; Cabalza, 2018; Bailey \& Gere, 2018). More so, the number of assigned students in terms of the counsellor-student ratio is also a concern because the ideal 1:500 guidance counsellor-to-student ratio is not usually followed in public schools (Valdez, 2018; Villar, 2007).

\subsection{Guidance counsellors and diverse challenges}

Guidance counsellors listen to and help individuals with their concerns. To achieve this objective, guidance counsellors help their clients to become more aware of their intrapersonal skills, and how these can be utilised to resolve the presenting problem (Gladding, 2013). Relative to competencies and techniques, a guidance counsellor should possess the right personal attributes and personality that is important to the profession (Lawson, 2007; Thompson, Amatea, \& Thompson, 2013). Through the healing process of counselling, guidance counsellors tend to provide and share a piece of themselves (Stebnicki, 2008). Counsellors often act as tough they should be a superhero to take on the heavy responsibility of caring for others, and harbour the belief that they are immune to challenges and stressors (Shallcross, 2013). These personal characteristics and personality traits of guidance counsellors can also be attributed to burnout and compassion fatigue (Lent \& Schwartz, 2012; Uy \& Hernandez, 2015). The following personal characteristics and personality traits can cause a higher level of burnout: age, years of experience, type a personality, idealism, rigidity, neuroticism and coping style (Lent \& Schwartz, 2012). In addition, extraversion and conscientiousness were found to have a significant difference in the level of compassion fatigue. Furthermore, a very significant difference was observed with neuroticism among personality traits and only was found to predict compassion fatigue (Uy \& Hernandez, 2015).

A guidance counsellor is not immune to the ills of life any more than an oncologist is immune to the risks of cancer. After all, guidance counsellors are humans with a personal crisis, pain, embarrassment 
and shame, which are inevitably reflected unfairly to their profession which adds to the weight of their sorrows (Moffat, 2018). In the same manner, guidance counsellors, who are mental health workers, are high at risk for professional burnout and they are susceptible to it. This is because on a daily basis, they listen to and support clients through some heavy and distressing issues (Bray, 2018).

Guidance counsellors face various challenges that include burnout, vicarious traumatisation and compassion fatigue, which can elevate the risks of stress (Tan \& Castillo, 2014). Professional burnout has been described as a state of psychological, spiritual, physical, and emotional exhaustion as result from chronic involvement or exposure in human service work, such as that of guidance counsellors (Newell \& Nelson-Gardell, 2014). Moreover, guidance counsellors must have an outlet to replenish and rejuvenate the emotion and energy expended in providing services; otherwise, they could experience burnout and exhaustion and might not give anything more to clients (Shallcross, 2011).

Extant studies on compassion fatigue as an aspect of the quality of life among practicing counsellors, especially in the Philippines are limited in the counselling literature (Lawson, 2007; Lawson \& Meyers, 2011). Based on the gathered literature, there is only one published research study completed by Uy and Hernandez (2015) who studied the personality traits and the predictor of compassion fatigue among guidance counsellors. Therefore, research and exploration on compassion fatigue among guidance counsellors in the Philippines are necessary. It is because counselling professionals also have been found susceptible to compassion fatigue (Craig \& Sprang, 2010).

\subsection{Compassion fatigue}

Compassion fatigue was first defined by Figley (1995a) as "cost of caring" among helping professionals who listen to clients' stories of fear, pain and suffering. It is also the feeling among helping professionals of losing their sense of self to the clients they provide care or service (Figley, 1995a). Figley studied the phenomenon for 10 years and called compassion fatigue a form of burnout, a kind of "secondary victimisation" (Figley, 1983). Likewise, it has also been defined as a functional bearing of witness to the suffering of others (Lawson, 2007).

Stamm (2010) considered compassion fatigue as a negative professional quality of life. The construct of professional quality of life is derived from Figley (1995b) the Compassion Fatigue Self-Test (CFST; Figley, 1995b; Stamm, 2005). Across researches that tested and revised CFST, the refinement of the CFST resulted in the constructs (in the form of subscales) of compassion satisfaction, compassion fatigue, burnout and secondary traumatic stress. As a result, professional quality of life represents how an individual feels in relation to their work as a helper (Stamm, 2010). The feelings associated with quality of life are influenced by both the positive experiences, which describe satisfaction, altruism and fulfillment; and negative experiences, which describe frustration, emotional turmoil and stress.

Stamm (2010) identified two specific components of compassion fatigue, which are secondary traumatic stress and burnout. Secondary traumatic stress is emotional threat that comes from close contact with people who had experienced a trauma (Figley, 1983, 1995b; Figley \& Kleber, 1995; Stamm, 2010). It is also considered an occupational hazard of helping professionals (Bride, Hatcher, \& Humble, 2009). Additionally, it is described as being preoccupied with thoughts of individuals who are helped (Stamm, 2010). It has similar symptoms as Post Traumatic Stress Syndrome (PTSD; Jenkins \& Baird, 2002). Figley (1995b) renamed secondary traumatic stress to compassion fatigue to lessen the stigma linked with its name. In addition, Stamm $(1995,2005)$ argues that burnout is a byproduct of secondary traumatic stress. Burnout is a professional weakening from physical and mental tiredness due to involvement in emotionally challenging interactions, which can be developed over time and can damage an individual's outlook (Freudenberger, 1989; Maslach, 2003; Maslach, Schaufeli, \& Leiter, 2001). Three-factor model of burnout, which was identified by Maslach (2003), to further define burnout: (a) emotional exhaustion; (b) depersonalisation and (c) reduced personal accomplishment. Burnout can affect job effectiveness because it is about feelings of hopelessness and difficulties in 
dealing with work (Stamm, 2010). Burnout is common among helping professionals (Kottler \& Hazler, 1996; Norcross \& Guy, 2007).

In this study, add-on factors can be attributed to compassion fatigue and its subscales among guidance counsellors and this can build up empirical findings in the theory of compassion fatigue. Work-related factors among guidance counsellors like counsellor-student ratio (Gunduz, 2012; Lambie, 2007; Wilkerson, 2009; Wilkerson and Bellini, 2006; Carrell, 2006; McCarthy, Van Horn Kerne, Caifa, Lambert, \& Guzman, 2010; Udipi, 2007; Dean, 2014) and years of experience (Hoang, 2014; Lindsay, 2012; Butler \& Constantine, 2005) can be related factors to compassion fatigue based on literature. Salary among guidance counsellors can be a factor of compassion fatigue because it is one of the issues and concerns that exist in the Philippines (Lagon, 2016; Cabalza, 2018; Bailey \& Gere, 2018). However, type of employment does not have support in the literature, which can be attributed to compassion fatigue wherein it can be assumed that it is a factor that will be explored in this study. Personality traits among guidance counsellors can be attributed to compassion fatigue (Uy \& Hernandez, 2015; Luck, 2009; Thompson, Amatea, \& Thompson, 2013; Lent and Schewartz, 2012) as presented in the literature. All the constructs presented, based on the gathered literature, compassion fatigue and its factors among guidance counsellors will be explored. Figure 1 shows the conceptual diagram of the study.

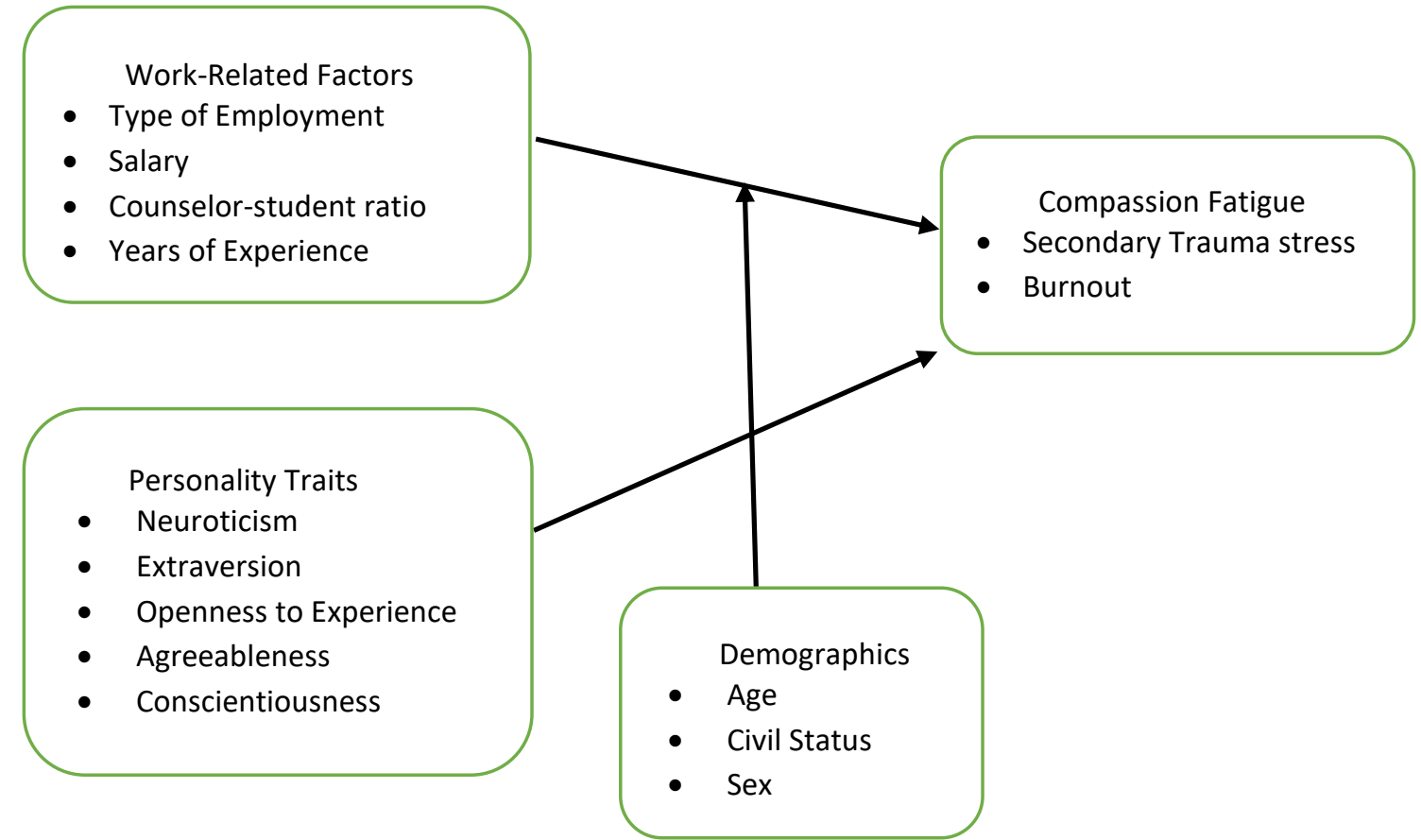

Figure 1. The conceptual model on analysing the factors of compassion fatigue among guidance counselors

Based on gathered literature, the model was conceptualised to explore compassion fatigue among guidance counsellors in which work-related factors and personality traits contribute to compassion fatigue. In the given concept model, demographics of guidance counsellors can have a moderating effect on the relationship between work-related factors, personality traits and compassion fatigue. In a previous study, age was found to have a negative relationship to compassion fatigue (Burnett, 2018), and to its subscale on secondary traumatic stress (Siegel \& Schembari, 2015), as well as burnout (Randall, 2007). However, on civil status and sex, there were no identified studies that found a moderating relationship with compassion fatigue and this will be explored in this study.

The research was guided by the following research questions: (1) How may the Guidance Counsellors in Central Luzon, Region 3 be described on demographics, work-related factors, 
personality traits, compassion fatigue in terms of burnout and secondary trauma stress? (2) What factors in work-related and personality traits significantly predict burnout? (3) What factors in workrelated and personality traits significantly predict secondary trauma stress? (4) What demographic variables (i.e., age, sex and civil status) moderate the relationship between work-related factors, personality traits and burnout? (5) What demographic variables (i.e., age, sex and civil status) moderate the relationship between work-related factors, personality traits and secondary trauma stress?

\section{Methodology}

Guidance counsellors in State Universities and Colleges (SUC), Local Colleges and Universities (LCU), Private schools (College, High School and Elementary) and public school (elementary and high school) in Central Luzon - Region 3, Philippines, were the source of participants in the study. The participants of the study are guidance counsellors in Central Luzon - Region 3, Philippines. Ninety-two participants were included in the study. Table 1 shows the type of school where the participants are employed. Most of the participants were coming from state universities and colleges having a frequency of 32 with a percentage of $34.8 \%$.

Table 1. Guidance counsellors' type of school where they are employed

\begin{tabular}{lcc}
\hline \multicolumn{1}{c}{ Type of school } & $\boldsymbol{F}$ & $\boldsymbol{\%}$ \\
\hline State university and college & 32 & 34.8 \\
Local college university & 11 & 12.0 \\
Private school (college) & 25 & 27.2 \\
Private school (HS) & 10 & 10.9 \\
Public school (HS) & 11 & 12.0 \\
Private school (elementary) & 3 & 3.3 \\
Total & 92 & 100 \\
\hline
\end{tabular}

\subsection{Instruments}

The study utilised a questionnaire about the general demographics of the participants. The selfreport form requested the following information from participants: (a) name - optional; (b) age; (c) sex; (d) type of university/college setting (State Universities \& Colleges and Local College \& Universities); (e) years of experience as guidance counsellor; (f) monthly salary; (g) civil status; (h) type of employment and (i) guidance counsellor-student ratio. The ProQOLs was the main instrument of the study. A 30-item self-report instrument measured compassion satisfaction and compassion fatigue. Compassion fatigue has two subscales, which include burnout and secondary traumatic stress. Generally, it comprises three subscales distributed to 10 items on each subscale, which includes (a) compassion satisfaction, (b) burnout and (c) secondary traumatic stress. Compassion fatigue is represented by burnout and secondary traumatic stress, which are combined (Stamm, 2010).

The original version of ProQOL was developed in English. It is translated into 27 languages, like Finnish, French, Filipino, German, Hebrew, Italian, Japanese, Spanish and Croat. The tool uses a 5-point Likert-style format wherein participants are requested to give their rating on each item based on their professional life. The following are the responses options which are " 5 = Very Often," "4 = Often," "3 = Sometimes," "2 = Rarely" and "1 = Never." Each scale based on the instrument has 10 items. To score each dimension, researchers first need to reverse score items 1, 4, 15, 17 and 29 wherein the summation of each element will define the level of compassion satisfaction, burnout and secondary traumatic stress of the participants (Stamm, 2010).

Stamm (2010) reported that the ProQOL has a good construct validity. The reported Cronbach's Alphas of the three subscales are as follows. The inter-scale correlations show $2 \%$ shared variance 
$(r=-0.23$; co- $\sigma=5 \% ; n=1,187)$ with secondary traumatic stress and $5 \%$ shared variance $(r=.-0.14$; co- $\sigma=2 \% ; n=1,187$ ) with burnout. While there is a shared variance between Burnout and Secondary Traumatic Stress the two scales measure different constructs with the shared variance likely reflecting the distress that is common to both conditions. The shared variance between these two scales is $34 \%$ ( $r=0.58$; co- $\sigma=34 \% ; n=1,187)$. Furthermore, reported alpha scale reliability for compassion satisfaction is 0.88 ; alpha scale reliability for burnout is 0.75 and alpha scale reliability for secondary traumatic stress is 0.81 (Stamm, 2010).

The ProQOLs was used in various researches that study counselling practitioners. In the United States, Lawson (2007) examined the career sustaining behaviours and ProQOL of 1,000 American Counselling Association (ACA) members. The study produced a $50.9 \%$ response rate $(N=501)$. It was found out that the three scales had an average score of Compassion Satisfaction $(M=39.84, S D=6.43$, Alpha $=0.77)$; Compassion Fatigue $(M=10.05, \mathrm{SD}=5.91$, Alpha $=0.85)$ and Burnout $(M=18.37$, $\mathrm{SD}=6.00$, Alpha $=0.82$ ). Lawson (2007) found that those participants in K-12 settings scored $(M=19.70, S D=6.29)$ lower on the Burnout scale than their counterparts in community settings $(M=19.84, S D=6.88)$, but higher than practitioners in private practice $(M=15.77, S D=6.04)$, $F(5,456)=8.22, p=0.000$. Additionally, $\mathrm{K}-12$ practitioners scored $(M=11.89, \mathrm{SD}=6.40)$ higher in Compassion Fatigue when compared to private practitioners $(M=8.26, S D=5.25)$ and practitioners in community settings $(M=10.31$, SD $=5.78), F(5,456)=5.78, p<0.035$. There were no group differences in Compassion Satisfaction scale scores. In addition, there were no significant differences in the ProQOLs scores and demographic factors. Importantly, the authors used the third version of the ProQOLs, yielding the following internal consistency coefficients: Compassion Satisfaction (0.84), Burnout (.78) and Secondary Traumatic Stress (.80) (Lawson, 2007).

The NEO PI-R is a standard questionnaire measuring the five major dimensions of personality, which are neuroticism, extraversion, openness to experience, agreeableness and conscientiousness. It is a 240-items self-report test that is answerable with the following options: "SD = Strongly Disagree", "D = Disagree", "N = Neutral", "A = Agree" and "SA = Strongly Agree". The questionnaire can be answered in 35-45 minutes wherein it can provide a systematic assessment of emotional, interpersonal, experiential, attitudinal and motivational styles. The NEO PI-R is validated against other personality inventories, as well as projective assessments (McCrae and Costa, 2010).

Based on the test manual of NEO PI-R, it provides good support in looking at reliability and validity. Coefficients at $0.86-0.95$ for both forms (self and observer) state its good internal consistency. Three of the subtest namely Neuroticism, Extraversion and Openness to Experience had good long-term test-retest reliability. Some evidence for construct, convergent and divergent validity was provided through correlations with Myers-Briggs Type Indicator, Personality Research Form, Minnesota Multiphasic Personality Inventory and the Self Directed Search (McCrae and Costa, 2010).

\section{Analyses}

Descriptive statistics was used to describe the personality traits, burnout and secondary trauma stress as elements of compassion fatigue of the participants. Multiple regression stepwise method was used to identify predictors of burnout and secondary trauma stress as elements of compassion fatigue; to work-related (counsellor-student ratio, salary, years of experience and job security) and personality traits. Moreover, demographic profiles were included in the multiple regression stepwise method to explore the moderating effect of the relationship between work-related factors, personality traits and compassion fatigue through the selected demographics (age, civil status and sex) of the participants.

\section{Results}

Table 2 presents the demographics and work-related factors of the participants. In terms of demographics, most of the participants belong to the age bracket of 34-39 with $29.3 \%$, followed by 
28-33 and 40-45, which are closely relative in terms of number. This reveals that the respondents are relatively young. Most of the participants are married with a percentage of $53.3 \%$ followed by a single with a percentage of $40.2 \%$. Most of the participants are female with a percentage of $78.3 \%$ followed by male participants with a percentage of $21.7 \%$.

In terms of work-related factors, the type of employment of participants shows that most of them are in permanent status with a percentage of $92.4 \%$. The salary of the participants falls in the salary range of $20,001-24,000$ pesos with a percentage of $35 \%$ followed by salary range $24,001-26,000$ with a percentage of $15 \%$. This confirms that most guidance counsellors who participated in the study receive the same monthly pay of PHP 20,179 as a Teacher I in the Philippine Department of Education (DepEd). Guidance counsellors are being compensated as the same as a Teacher I, although guidance counsellors are required to have a higher educational qualification than a teacher before taking a licensure exam (Valdez, 2018). With the current salary of most of the guidance counsellors, they should be adequately compensated so that provisions of the mental health law on handling the mental health education in schools can be handled properly by well-compensated guidance counsellors (Malipot, 2018). The counsellor-student ratio is described with a mean score of $1,721.47$ and a standard deviation of 1,943.99. This implies that the 1 counsellor per 500 students (1:500) is not usually followed (Villar, 2007; Valdez, 2018). Identifying the acceptable ratio that is prescribed by the Commission of Higher Education (CHED) of having a guidance counsellor to student population is at 1 counsellor to 1,000 students (1:1000) is not followed based on the mean score of counsellor-student ratio. The years of experience of the participants is described with a mean score of 13.60 and a standard deviation of 8.39. This implies that most of the guidance counsellor who participated in the study have enough years of experience in the practice of guidance and counselling.

Table 2. Demographics and work-related factors ( $N=92$ guidance counsellors)

\begin{tabular}{lcc}
\hline $\begin{array}{c}\text { Demographic profile } \\
\text { Age of participants }\end{array}$ & $\boldsymbol{F}$ & $\boldsymbol{\%}$ \\
\hline $22-27$ & 8 & 8.7 \\
$28-33$ & 18 & 19.6 \\
$34-39$ & 27 & 29.3 \\
$40-45$ & 16 & 17.4 \\
$46-51$ & 9 & 9.8 \\
$52-57$ & 12 & 13.0 \\
$58-63$ & 2 & 2.2 \\
Civil status & & \\
Single & 37 & 40.2 \\
Married & 49 & 53.3 \\
Separated & 2 & 2.2 \\
Widowed & 4 & 4.3 \\
Sex & & \\
Male & 20 & 21.7 \\
Female & 72 & 78.3 \\
Work-related factors & & \\
Type of employment & & \\
Permanent & 85 & 92.4 \\
Probationary & 4 & 4.3 \\
Casual & 3 & 3.3 \\
Salary & & \\
10,000-20,000 & 9 & 10 \\
20,001-24,000 & 32 & 35 \\
24,001-26,000 & 14 & 15 \\
26,001-30,000 & 6 & 7 \\
30,001-35,000 & 13 & 14 \\
& &
\end{tabular}


Estacio, R. D. (2019). The factors of compassion fatigue among guidance counsellors. Global Journal of Guidance and Counseling in Schools: Current Perspectives, 9(3), 115-130. https://doi.org/10.18844/gigc.v9i3.4343

\begin{tabular}{lcc} 
35,001-40,000 & 6 & 7 \\
$45,001-50,000$ & 6 & 7 \\
50, 001-up & 6 & 7 \\
& Mean & SD \\
Counsellor-student ratio & $1,721.47$ & $1,943.99$ \\
Years of experience & 13.60 & 8.39 \\
\hline
\end{tabular}

Table 3 presents the personality traits of the participants presented in mean and standard deviation. It showed that participants have a low level of neuroticism $(M=1.43, \mathrm{SD}=0.37)$. The professional manual of NEO-PR describes the participants as emotionally stable, even-tempered and calm and can cope easily with the stressful situation without being upset or rattled (McCrae \& Costa, 2010). In terms of extraversion, participants have average levels of extraversion $(M=2.43, S D=0.31)$. Professional manual of NEO-PR, participants are described to have neutral levels of excitement; being relaxed and active; and being warm and reserved (McCrae \& Costa, 2010). Likewise, the personality trait on openness to experience of participants falls on the neutral levels $(M=2.36, S D=0.24)$. This implies that participants may balance being practical and ideal, have a neutral curiosity about the inner and other worlds and have balanced views in valuing situations (McCrae \& Costa, 2010). In terms of agreeableness, participants have high level of agreeableness $(M=2.62, S D=0.27)$. This indicates that participants are sincere, candid and frank have an active concern for others' welfare, deep sense of sympathy and empathy on the needs of others (McCrae \& Costa, 2010). These descriptions confirm the characteristics of participants that tend to provide and share a piece of themselves (Stebnicki, 2008) and the feeling of having heavy responsibility of caring for others (Shallcross, 2013). This implies that participants usually have average to high agreeableness in support of the study of Uy \& Hernandez (2015) that guidance counsellors were found to have an average level of agreeableness on their personality trait. More so, the high level of agreeableness confirms the study of Luck (2009) that counsellors are likely to be agreeable as their personality trait (Luck, 2009). In terms of conscientiousness personality trait, participants have high levels to be conscientious $(M=2.83$, $\mathrm{SD}=0.35$ ). This describes that participants have high control of impulses, active in the processing of plans, organising and carrying out tasks (McCrae \& Costa, 2010). This confirms the findings of Luck (2009) that counsellors are likely to have a conscientious personality trait.

Table 3. Personality trait

\begin{tabular}{lcc}
\hline \multicolumn{1}{c}{ Personality trait } & Mean & SD \\
\hline Neuroticism & 1.43 & 0.37 \\
Extraversion & 2.43 & 0.31 \\
Openness to experience & 2.36 & 0.24 \\
Agreeableness & 2.62 & 0.27 \\
Conscientiousness & 2.83 & 0.35 \\
\hline
\end{tabular}

Table 4 reveals the burnout and secondary trauma stress as components of compassion fatigue among participants. The participants are described to have low levels or rarely experience of burnout $(M=1.90, S D=0.42)$. This means that participants tend to have positive feelings about their ability to be effective in their work as a helper (Stamm, 2010). This confirms that guidance counsellors are described to have less burnout as an element of compassion fatigue based on previous studies (Thompson, Amatea, \& Thompson, 2014; Uy \& Hernandez, 2015). Similarly, the secondary trauma stress of participants shows low levels or rarely experience of secondary trauma stress $(M=2.01$, SD $=0.49$ ). Participants have a low impact on secondary trauma stress after having secondary exposure to extremely or traumatically events (Stamm, 2010). Furthermore, moderate-to-low levels of secondary trauma stress do not have notable distress from their work as a helper (Stamm, 2010). The descriptive result of compassion fatigue among participants on having rarely experience of burnout and secondary traumatic stress can be explained on the personality trait conscientiousness. Most 
Estacio, R. D. (2019). The factors of compassion fatigue among guidance counsellors. Global Journal of Guidance and Counseling in Schools: Current Perspectives, 9(3), 115-130. https://doi.org/10.18844/gigc.v9i3.4343

guidance counsellors are described to be conscientious and have high control of impulses, active in the processing of plans, organising and carrying out tasks (McCrae \& Costa, 2010).

Table 4. Guidance counsellors' burnout and secondary trauma stress as components of compassion fatigue

\begin{tabular}{lll}
\hline Compassion fatigue & Mean & SD \\
\hline Burnout & 1.90 & 0.42 \\
Secondary trauma stress & 2.01 & 0.49 \\
\hline
\end{tabular}

Table 5 shows that neuroticism, extraversion and agreeableness personality trait were found to predict burnout. Multiple linear regression was calculated to predict burnout based on neuroticism, extraversion and agreeableness. A significant regression equation was found $(F(1,90)=19.585$, $p<0.000$ ) with an $R^{2}$ of 0.400 . The $R^{2}$ value of 0.400 describes the variability of the regression model. This means that $40 \%$ variability in burnout can be identified in neuroticism, extraversion and agreeableness personality traits. Participants' predicted burnout is equal to $3.219+0.421(x 1)-0.375$ $(\mathrm{x} 2)-0.385(\mathrm{x} 3)$, where $\mathrm{x} 1=$ Neuroticism, $\mathrm{x} 2$ = Extraversion, $\mathrm{x} 3=$ Agreeableness. These findings confirm the study of Uy and Hernandez (2015), which affirms neuroticism and extraversion as predictors of compassion fatigue in looking at the element of burnout. Likewise, the study of Luck (2009) confirms neuroticism and agreeableness to be predictors of developing compassion fatigue and burnout. Furthermore, the study of Thompson, Amatea, \& Thompson (2013) verifies the findings that burnout is accounted for neuroticism. Moreover, the study of Lent and Schwartz (2012) verifies the findings that the strongest predictor of burnout is identified in the personality trait neuroticism.

Table 5. Model summary of personality traits predicting burnout

\begin{tabular}{lccccc}
\hline \multicolumn{1}{c}{ Model } & $\boldsymbol{R}^{\mathbf{2}}$ & Individual $\boldsymbol{R}^{\mathbf{2}}$ & $\boldsymbol{B}$ & Constant & $\boldsymbol{p}$-Value \\
\hline Neuroticism & 0.268 & 0.268 & 0.421 & 3.219 & 0.000 \\
Extraversion & 0.347 & 0.079 & -0.375 & & 0.002 \\
Agreeableness & 0.400 & 0.053 & -0.385 & & 0.006 \\
\hline
\end{tabular}

a. Predictors: neuroticism, extraversion, agreeableness

b. Dependent variable: burnout

Table 5 reveals that salary as a work-related factor was found to be a predictor of burnout. Multiple linear regression was calculated to predict burnout based on salary as a work-related factor. A significant relationship was found $(F(1,90)=4.469, p<0.037)$ with an $R^{2}$ of 0.047 . The $R^{2}$ value of 0.047 describes the variability of the regression model. This means that $4.7 \%$ variability in burnout can be identified in salary as work-related factors of the participants. Participants' predicted burnout is equal to $2.038-4.378 \mathrm{E}-6(\mathrm{x} 1)$, where $\mathrm{x} 1$ = Salary. This confirms that the issues and concerns on the salary of guidance counsellors inevitably exist in the Philippines (Cabalza, 2018; Bailey \& Gere, 2018; Lagon, 2016). This is a concern among guidance counsellors, which can predict burnout based on findings. Moreover, this substantiates the battle cry for the increased salary among guidance counsellors, which predisposes their concerns and issues to properly compensate for their work (Andolong, 2018).

Table 6. Model summary of work-related factors predicting burnout

\begin{tabular}{ccccc}
\hline Model & $\boldsymbol{R}^{\mathbf{2}}$ & $\boldsymbol{B}$ & Constant & $\boldsymbol{p}$-Value \\
\hline Salary & 0.047 & $-4.378 \mathrm{E}-6$ & 2.038 & 0.037 \\
\hline
\end{tabular}

a. Predictor: salary

b. Dependent variable: burnout

Table 7 revealed that of all the personality trait factors, only neuroticism was found to predict secondary trauma stress. Multiple linear regression was calculated to predict burnout based on neuroticism. A significant regression equation was found $(F(1,90)=25.244, p<0.000)$, with an $R^{2}$ of 0.219 . The $R^{2}$ value of 0.219 describes the variability of the regression model. This means that $21.9 \%$ 
variability in secondary trauma stress can be explained in neuroticism personality trait. Participants' predicted secondary trauma stress is equal to $11.368+.127(\mathrm{x} 1)$ wherein $\mathrm{x} 1=$ Neuroticism. In considering secondary trauma stress as an element of compassion fatigue, the findings confirm the previous study done by Lent and Schwartz (2012); Uy and Hernandez (2015) in which compassion fatigue is a predictor of neuroticism.

In work-related factors among the participants, there were no identified factors that predict secondary trauma stress. The $p$-value on the analysis of variance found no significant regression equation $(F(4,90)=0.236, p \nless 0.918)$, wherein $p$-value should be $<0.05$. Based on the multiple regression stepwise method, there is no moderating relationship on selected demographic variables between work-related factors, personality traits and burnout. Likewise, there is no moderating relationship on selected demographic variables between work-related factors, personality traits and secondary trauma stress. Neuroticism, extraversion, and conscientiousness categorised as personality traits factors and salary as categorised by work-related factors were found out to be accounted to burnout.

Table 7. Model summary of predictors of secondary trauma stress of guidance counsellors

\begin{tabular}{cccccc}
\hline Model & $\boldsymbol{R}$ & $\boldsymbol{R}^{\mathbf{2}}$ & $\boldsymbol{B}$ & Constant & $\boldsymbol{p}$-Value \\
\hline Neuroticism & 0.468 & 0.219 & 0.127 & 1.137 & 0.000
\end{tabular}

a. Predictor: neuroticism

b. Dependent variable: secondary traumatic stress

\section{Implications}

Based on the findings, mindfulness counselling interventions and practices can be applied to lessen the possibility of compassion fatigue among guidance counsellors. According to Whitbourne (2017), mindfulness is suggested to help highly neurotic people. In mindfulness, people can concentrate on and accept one's thoughts and feelings. It can focus the attention of their maladaptive ways of thinking (Whitbourne, 2017).

Schools should hire more guidance counsellors in order to address this difficulty and to address the concern on counsellor-student ratio. The result of the study will be communicated to Region 3, Philippines local chapters of Philippine Guidance and Counseling Association on what course of action they can do based on the said concern.

The findings of the study can be convinced to the Philippine Guidance and Counseling Association National chapter to be a basis in addressing concerns and issues on the salary of guidance counsellors, which is identified as a predictor of burnout as an element of compassion fatigue. The salary of the guidance counsellors should be upgraded to boost their financial morale so that they can be adequately paid to recognise their efforts as helping professionals. If this problem for guidance counsellor will be addressed, it will have an impact on the whole salary system of guidance counsellors in the Philippines. The predictor model of burnout and secondary trauma stress can be utilised in understanding more what lies in the factors of compassion fatigue. This can be a basis in the enhancement of personality traits in order to prevent burnout and secondary trauma stress as elements of compassion fatigue.

Furthermore, the study may be replicated by future researchers in consideration of a wider scope of participants, adding other variables, which are correlated to compassion fatigue, doing comparative and longitudinal analysis of different guidance counsellors to other regions of the Philippines. Furthermore, salary and civil status can be reconsidered on describing its satisfaction status added as a new variable on work-related factors and demographics among guidance counsellors. 
Estacio, R. D. (2019). The factors of compassion fatigue among guidance counsellors. Global Journal of Guidance and Counseling in Schools: Current Perspectives, 9(3), 115-130. https://doi.org/10.18844/gigc.v9i3.4343

\section{Conclusion}

The results of the study have identified factors of burnout and secondary trauma stress as elements of compassion fatigue. Predictors of compassion fatigue are identified in its elements of burnout and secondary trauma stress. The salary under work-related factors is identified to significantly predict burnout. Neuroticism, extraversion and conscientiousness personality traits factors are significantly identified as predictors of burnout. A neuroticism personality trait is significantly found to be a predictor of secondary trauma stress. Based on the two elements of compassion fatigue, neuroticism was found to be the best predictor among personality traits.

\section{References}

Abrenica, A. (2012). Research: to enhance guidance practice. Abrenica Psychological Diagnostic Publishing.

American School Counselor Association. (2009). The professional school counselor and student mental health. Alexandria, VA: Author.

American School Counselor Association. (2012). The ASCA national model: a framework for school counseling programs (2nd ed.). Alexandria, VA: Author.

Andolong, I. (2018). DepEd calls for increase in guidance counselors' pay. CNN Philippines. Retrieved July 13, 2018, from http://cnnphilippines.com/news/2018/07/13/Guidance-counselor-salary-public-school.html

Baggerly, J. \& Osborn, D. (2006). School counselors' career satisfaction and commitment: correlates and predictors. Professional School Counseling, 9(3), 197-205.

Bailey, J. \& Gere, B. (2018). Identify colors to create a rainbow of cohesion in the workplace for helping professionals. Counseling Today: A Publication of the American Counseling Association. Retrieved from https://ct.counseling.org/tag/topic-ct-counselor-wellness/

Baranowsky, A. B. (2002). The silencing response in clinical practice: on the road to dialogue. In C. R. Figley (Ed.), Treating compassion fatigue (pp. 155-170). New York, NY: Brunner-Routledge.

Bardhoshi, G. (2012). The relationship between assignment of non-counseling duties and burnout among professional school counselors. ProQuest LLC 2012.

Baron-Cohen, S.,, Knickmeyer, R. C., \& Belmonte, M. K. (2005). Sex differences in the brain: implications for explaining autism. Science, 310(4), 819-823.

Blanchette, J. (2010). Compassion fatigue, forgiveness, and empathy in forster parents. ProQuest. 3442295.

Blount, A., Bjornsen, A., \& Moore, M. (2018) Work values, occupational engagement, and professional quality of life in counsellors-in-training: assessments in a constructivist- based career counseling course. The Professional Counselor, 8(1), 60-72. Retrieved from http://tpcjournal.nbcc.org @ 2018 NBCC, Inc. and Affiliates.

Bonomi, A., Patrick, D., Bushnell, D., \& Martin, M. (2000). Validation of the United States' version of the World Health Organization Quality of Life (WHOQOL) instrument. Journal of Clinical Epidemiology, 53(1), 1-12.

Bray, B. (2018). The battle against burnout. Counseling Today: A Publication of the American Counseling Association. Retrieved from https://ct.counseling.org/2018/03/the-battle-against-burnout/\#comments

Bride, B. E., Hatcher, S. S., \& Humble, M. N. (2009). Trauma training, trauma practices, and secondary traumatic stress among substance abuse counselors. Traumatology, 15(2), 96-105.

Burnett, K. (2018). A study on the relationship and predictability of selected social and work-related factors on the degree of compassion fatigue among licensed mental health professionals. Published by ProQuest 2018.

Butler, S. K. \& Constantine, M. (2005). Collective self-esteem and burnout in professional school counselors. Professional School Counseling, 9(1), 55-62.

Cabalza, D. (2018). DepEd looking for 3.5K guidance counselors. Philippine Daily Inquirer, Retrieved July 17, 2018, from http://newsinfo.inquirer.net/1010901/deped-looking-for-3-5k-guidance-counselors.

Can, N. (2018). Caring for beginning counselors: the relationship between empathy, supervisory working alliance, resilience, wellness, and compassion fatigue among counselors-in-training. ProQuest LLC 2018. 
Estacio, R. D. (2019). The factors of compassion fatigue among guidance counsellors. Global Journal of Guidance and Counseling in Schools: Current Perspectives, 9(3), 115-130. https://doi.org/10.18844/gigc.v9i3.4343

Carrell, S. A. (2006). The student-to-counselor ratio: does it matter? Contributions to Economic Analysis \& Policy, $5(1)$.

Chapman, E., Baron-Cohen, S., Auyeung, B., Knickmeyer, R., Taylor, K., \& Hackett, G. (2006). Fetal testosterone and empathy: evidence from the empathy quotient (EQ) and the 'reading the mind in the eyes' test." Social Neuroscience, 1(2):135-148.

Cicognani, E., Pietrantoni, L., Palestini, L., \& Prati, G. (2009). Emergency workers' quality of life: the protective role of sense of community, efficacy beliefs and coping strategies. Social Indicators Research, 94(3), 449-463.

Collins, S. \& Long, A. (2003). Working with the psychological effects of trauma: consequences for mental healthcare workers - a literature review. Journal of Psychiatric \& Mental Health Nursing, 10(4), 417-424.

Corey, G. (2013). Theory and practice of counseling and psychotherapy (9th ed., pp. 18-34). Cengage Learning. .

Costa, D. M. (November 7, 2005). Compassion fatigue: self-care strategies for practitioners. OT Practice, 13-18.

Cox, D. W., Krieshok, T. S., Bjornsen, A. L., \& Zumbo, B. D. (2015). Occupational engagement scale-student: development and initial validation. Journal of Career Assessment, 23, 107-116. doi:10.1177/ 1069072714523090

Craig, C. \& Sprang, G. (2009). Exploratory and confirmatory factor analysis of the trauma practices questionnaire. Research on Social Work Practice, 19, 221-233.

Craig, C. D. \& Sprang, G. (2010). Compassion satisfaction, compassion fatigue, and burnout in a national sample of trauma treatment therapists. Anxiety, Stress and Coping, 23, 319-339.

Cruz, M. (2018). Pay hike for guidance counselors sought. Manilastandard.net. Retrieved July 21, 2018, from http://manilastandardtoday.com/news/national/271082/pay-hike-for-guidance-counselors-sought.html

Curtis, T. (2018). Women are more prone to compassion fatigue - here's how to deal with it. Retrieved from https://fairygodboss.com/articles/women-are-more-prone-to-compassion-fatigue-here-s-how-to-dealwith-it

Dean, A. (2014). An examination of the relationship among secondary traumatic stress, compassion satisfaction and burnout in licensed professional counselors. Published by ProQuest LLC (2014).

DeKruyf, L., Auger, R., \& Trice-Black, S. (2013). The role of school counselors in meeting students' mental health needs: examining issues of professional identity. Professional School Counseling, 16(5, Special Issue on School Counselors and Student Mental Health, Part 2, January 2013), 271-282. Retrieved from https://www.schoolcounselor.org/asca/media/asca/ASCAU/Mental-Health-Specialist/DeKruyf.pdf

Feingold, A. (1994). Gender differences in personality: a meta-analysis. Psychological Bulletin, 116(3), 429-456.

Felce, D. \& Perry, J. (1995). Quality of life: its definition and measurement. Research in Development Disabilities, 16(1, January-February 1995), 51-74. Retrieved from https://www.sciencedirect.com/science/article/pii/ 0891422294000288 ?via\%3Dihub

Figley, C. R. (1983). Catastrophes: an overview of family reactions. In C. R. Figley \& H. I. McCubbin (Eds.), Stress and the family: coping with catastrophe (Vol. 2, pp. 3-20). New York, NY: Brunner/Mazel.

Figley, C. (1995a). Compassion Fatigue: Coping with Secondary Traumatic Stress Disorder in Those Who Treat the Traumatized. Taylor \& Francis Group LLC 1995

Figley, C. R. (1995b). Compassion fatigue: toward a new understanding of the costs of caring. In B. H. Stamm (Ed.), Secondary traumatic stress (pp. 3-28). Lutherville, MD: Sidran Press.

Figley, C. (1998). Burnout in families: the systemic cost of caring. Clermont, FL: CRC Press.

Figley, C. R. (2002). Compassion fatigue: psychotherapists' chronic lack of self-care. JCLP/In Session: Psychotherapy in Practice, 58, 1433-1441.

Figley, C. R. \& Kleber, R. J. (1995). Beyond the "victim": secondary traumatic stress. In R. J.

Freudenberger, H. J. (1989). Burnout: past, present, and future concerns. Loss, Grief, \& Care, 3, 1-9.

Garner, B. R. (2006). The impact of counselor burnout on therapeutic relationships: a multilevel analytic approach. Retrieved from http://citeseerx.ist.psu.edu/viewdoc/download?doi=10.1.1.549.9598\&rep= rep1\&type=pdf

Gillespie, S. (2016). Spirituality, mindfulness, self-compassion, and religiosity as predictors of compassion fatigue and compassion satisfaction in therapists. ProQuest LLC 2016.

Gladding, T. (2013). Counseling: a comprehensive profession (7th ed., pp. 32-40). Pearson.. 
Estacio, R. D. (2019). The factors of compassion fatigue among guidance counsellors. Global Journal of Guidance and Counseling in Schools: Current Perspectives, 9(3), 115-130. https://doi.org/10.18844/gigc.v9i3.4343

Gunduz, B. (2012). Self-efficacy and burnout in professional school counselors. Educational Sciences: Theory \& Practice, 12(3), 1761-1767.

Gutierrez, D. \& Mullen, P. (2016). Burnout, stress and direct student services among school counselors. The Professional Counselor, 6(4), 344-359.

Hall, J. A. (1978). Gender effects in decoding nonverbal cues. Psychological Bulletin, 85(4), 845-857.

Hesse, A. (2002). Secondary trauma: how working with trauma survivors affects therapists. Clinical Social Work Journal, 30, 293-309.

Hoang, C. (2014). Exploring the relationship between compassion fatigue and the years of experience in addictions counsellors. ProQuest LLC 2014.

Retrieved from https://ched.gov.ph/blog/2018/03/16/78-local-universities-colleges-now-eligible-free-highereducation/

Retrieved from https://www.payscale.com/research/PH/Job=Guidance_Counselor/Salary

Ivankova, N. V., Creswell, J. W., \& Stick, S. L. (2006). Using mixed methods sequential explanatory design: from theory to practice. Field Methods, 18(1), 3-20.

Jacobson, J. (2004). Compassion fatigue among employee assistance program counselors. ProQuest Information and Learning Company 2004.

Jenkins, S. R. \& Baird, S. (2002). Secondary traumatic stress and vicarious trauma: a validation study. Journal of Traumatic Stress, 15, 423-432.

Kim, Y. \& Seidlitz, L. (2002). Spirituality moderates the effects of stress on emotional and physical adjustment. Personality and Individual Differences, 32(8), 1377-1390.

Kleber, R. J., Figley, C. R., \& Gersons, B. P. R. (Eds.) (2006)., Beyond trauma: cultural and societal dynamics (pp. 75-98). New York, NY: Plenum.

Koehler, C. (2013). Effects of a self-care intervention for counselors on compassion fatigue and compassion satisfaction. ProQuest LLC 2013.

Koenig, A. M., Eagly, A. H., Mitchell, A. A., \& Ristikari, T. (2011). Are leader stereotypes masculine? A metaanalysis of three research paradigms. Psychological Bulletin, 137(4), 616-642.

Kottler, J. \& Hazler, R. J. (1996). Impaired counselors: the dark side brought into light. Journal of Humanistic Education and Development, 34(3), 98-107.

Kottler, J. A. (2010). On being a therapist (4th ed.). San Francisco, CA: Jossey-Bass Publishers.

Lagon, H. (2016). Guidance and counseling in the Philippines: a journey to maturity. The Daily Guardian. Retrieved from https://thedailyguardian.net/option/guidance-and-counseling-in-the-philippines-ajourney-to-maturity/

Lambie, G. (2007). The contribution of ego development level to burnout in school counselors: implications for professional school counseling. Journal of Counseling and Development, 85, 82-88.

Lawson, G. (2007a). Counselor wellness and impairment: a national survey. Journal of Humanistic Counseling, Education and Development, 46, 20-34.

Lawson, G. (2007b). Wellness and impairment: a national survey. The Journal of Humanistic Counseling, Education and Development, 46, 20-35.

Lawson, G. \& Myers, J. E. (2011). Wellness, professional quality of life, and career-sustaining behaviors: what keeps us well?. Journal of Counseling and Development, 89(2), 163-171.

Lent, J. \& Schwartz, R. C. (2012). The impact of work setting, demographic characteristics, and personality factors related to burnout among professional counselors. Journal of Mental Health Counseling, 34(4), 355-372.

Lindsay, M. (2012). Multiple role balance, professional quality of life, and wellness among women employed as professional counselors. ProQuest Dissertations Publishing, 2012.

Linley, P.A. \& Joseph, S. (2007). Therapy work and therapists' positive and negative wellbeing. Journal of Social and Clinical Psychology, 26(3), 385-403.

Llewellyn, H. (2009). An exploratory study of the relationship between compassion fatigue and empathy in professional counselors. ProQuest.

Lopez, Y. (2013). Factors that contribute to burnout among elementary school counselors. Liberty University, July 2013 Retrieved from https://digitalcommons.liberty.edu/publications/ 
Estacio, R. D. (2019). The factors of compassion fatigue among guidance counsellors. Global Journal of Guidance and Counseling in Schools: Current Perspectives, 9(3), 115-130. https://doi.org/10.18844/gigc.v9i3.4343

Luck, T. (2009). The effect of personality characteristics and various aspects of genetic counseling on compassion fatigue, satisfaction, and burnout. Proquest 1467461.

Maddock, K. (2018). A list of helping professions: big hearts, big opportunities. Retrieved from https://www.snhu.edu/about-us/news-and-events/2018/03/helping-professions

Malipot, M. (2018). DepEd search for guidance counselors held back by low pay. Retrieved July 18, 2018, Manila Bulletin, from https://news.mb.com.ph/2018/07/18/deped-search-for-guidance-counselors-held-backby-low-pay/

Maslach, C. (2003). Burnout: the cost of caring. Cambridge, MA: Malor Books

Maslach, C., Schaufeli, W. B., \& Leiter, M. P. (2001). Job burnout. Annual Review of Psychology, 52, 397-422.

McCarthy, C., Van Horn Kerne, V., Caifa, N. A., Lambert, R. G., \& Guzman, M. (2010). An exploration of school counselors' demands and resources: relationship to stress, biographic, and caseload characteristics. Professional School Counseling, 13,146-158.

McCrae, R. \& Costa, P. (2010). NEO inventories for the NEO Personality Inventory-3 (NEO-PI-3), NEO Five-Factor Inventory-3 (NEO-FFI-3), NEO Personality Inventory-Revised (NEO-PI-R).

Mckim, L. \& Smith-Adcock, S. (2018). Trauma counsellors' quality of life. 2018 ProQuest LLC.

Moffat, G. K. (2018). The hurting counselor. Counseling Today: A Publication of the American Counseling Association. Retrieved from https://ct.counseling.org/tag/topic-ct-counselor-wellness/

Mullen, P. (2014). The contribution of practicing school counselors' self-efficacy and professional quality of life to their programmatic service delivery (Electronic theses and dissertations).

Munroe, J. F. (1995). Ethical issues associated with secondary trauma in therapists. In B. H. Stamm (Ed.), Secondary traumatic stress: self-care issues for clinicians, researchers and educators (pp. 211-229). Baltimore, MD: The Sidran Press.

Murray, K. M. (2010). Preventing professional school counselor burnout. In B. T. Erford (Ed.), Professional school counseling: $a$ handbook of theories, programs, and practices (pp.982-988). Austin, TX: PRO-ED.

Newell, J.M. \& Nelson-Gardell, D. (2014). A competency-based approach to teaching professional self-care: an ethical consideration for social work educators. Journal of Social Work Education, 50(3), 427-439.

Norcross, J. C. \& Guy, J. D. (2007). Leaving it at the office: a guide to psychotherapist selfcare. New York, NY: Guilford Press.

Nussbaum, M. C. \& Sen, A. (1993). The quality of life. Oxford England: Clarendon Press.

Paisley, P.O. \& MacMahon, G. (2001). The use of cognitive-behavioral therapy for counseling in schools. In N. Barwick (Ed.), Clinical counseling in schools (pp. 96-107). London: Routledge.

Phelps, A., Lloyd, D., Creamer, M., \& Forbes, D. (2009). Caring for careers in the after math of trauma. Journal of Aggression, Maltreatment \& Trauma, 18, 313-330.

Poghosyan, L., Clarke, S., Finlayson, M., \& Aiken, L. (2010). Nurse burnout and quality of care: cross-national investigation in six countries. Research in Nursing \& Health, 33(4), 288-298.

Pyne, J. R. (2011). Comprehensive school counseling programs, job satisfaction, and the ASCA national model. Professional School Counseling, 15(2), 88-97.

Radey, M., \& Figley, C. R. (2007). The social psychology of compassion. Clinical Social Work Journal, 35, 207-214.

Randall, K. J. (2007). Examining the relationship between burnout and age among Anglican clergy in England and Wales. Journal of Mental Health, Religion, and Culture, 10(1), 39-46.

Ribak-Rosenthal, N. N. (1994). Reasons individuals become school administrators, school counselors, and teachers. School Counselor, 41(3), 158-164.

Ringenbach, R. (2009). A comparison between counselors who practice meditation and those who do not on compassion fatigue, compassion satisfaction, burnout and self-compassion. UMI Microform 3361751 Copyright 2009 by ProQuest LLC.

Robinson, W. (2013). Posttraumatic growth and professional quality of life: an exploration of mental health practitioners working with military personnel and their family members. ProQuest LLC.

Roxas, M., David, A., Caligner, E. (2014). Examining the relations of compassion and forgiveness among Filipino counselors. Asian Journal of Social Sciences and Humanities, 3(1), 53-60. 
Estacio, R. D. (2019). The factors of compassion fatigue among guidance counsellors. Global Journal of Guidance and Counseling in Schools: Current Perspectives, 9(3), 115-130. https://doi.org/10.18844/gigc.v9i3.4343

Salazar-Clemena, R. (2014). Aligning school counseling program with the Philippine standards-based model and school improvement goal. Workshop conducted at the Annual Convention of the Philippine Guidance and Counseling Association at Sofitel Philippine Plaza Manila.

Scarborough, J. (2005). The school counselor activity rating scale: an instrument for gathering process data. Professional School Counseling, 8(3), 274-283.

Schellenberg, R. (2008). The new school counselor: strategies for universal academic achievement. Rowman Littlefield Education.

Shallcross, L. (2011). Taking care of yourself as a counselor. Counseling Today. Retrieved from https://ct.counseling.org/2011/01/taking-care-of-yourself-as-a-counselor/

Shallcross, L. (2013). Who's taking care of Superman?. Counseling Today: A Publication of the American Counseling Association. Retrieved from https://ct.counseling.org/2013/01/whos-taking-care-ofsuperman/

Siegel, K. \& Schembari, B. (2015). Risk factors associated with compassion fatigue in suicide hotline workers. Reseachgate.net publication April 2015 Retrieved from https://www.researchgate.net/publication/ 298215320

Simpson, L. R. (2005). Level of spirituality as a predictor of the occurrence of compassion fatigue among counseling professionals in Mississippi (Dissertation abstracts international, UMI No. 3190581).

Sirgy, M., Michalos, A. C., Ferriss, A. L., Easterlin, R. A., Pavot, W., \& Patrick, D. (2006). The quality-of-life research movement: past, present, and future. Social Indicators Research, 76(3), 343-466.

Skovholt, T. M. \& Trotter-Mathison, M. J. (2010). The resilient practitioner: burnout prevention and self-care strategies for counselors, therapists, teachers, and health professionals (2nd ed.). Boston, MA: Allyn and Bacon.

Sprang, G., Whitt-Woosley, A., \& Clark, J. J. (2007). Compassion fatigue, compassion satisfaction, and burnout: factors impacting a professional's quality of life. Journal of Loss and Trauma, 12(3), 259-280.

Stamm, B. H. (2005). The ProQOL manual. The professional quality of life scale: compassion satisfaction, burnout, and compassion fatigue/secondary trauma scales. Pocatello: Idaho State University and Sidran Press.

Stamm, B. H. (2010). The concise ProQOL manual (2nd ed.). Pocatello, ID: ProQOL.org.

Star, K. (2014). The relationship between self-care practices, burnout, compassion fatigue, and compassion satisfaction among professional counselors and counselors-in-training. ProQuest LLC.

Stauffer, M. (2013). A yoga intervention for counselors with compassion fatigue: a literature review and qualitative case study. Published by ProQuest LLC.

Stebnicki, M. (2008). Empathy fatigue, healing the mind, body, and spirit of professional counselors (pp. 19-28). New York, NY: Springer Publishing Company.

Stemen, A. (2014). Burnout: who's taking care of the care takers? Retrieved from https://www.socialworkhelper.com/2014/01/31/burnout-whos-taking-care-care-takers/

Super, D. E. (1970). Manual, work values inventory. Boston, MA: Houghton Mifflin Company.

Tan, S.-Y. \& Castillo, M. (2014). Self-care and beyond: a brief literature review from a Christian perspective. Journal of Psychology and Christianity, 33(1), 90+.

Thompson, E., Amatea, E., \& Thompson, E. (2014). Personal and contextual predictors of mental health counselors' compassion fatigue and burnout. Journal of Mental Health Counseling, 36(1), 58-77.

Thompson, I., Amatea, E., \& Thompson, E. (2013). Personal and contextual predictors of mental health counselor's compassion fatigue and burnout. Journal of Mental Health Counseling, 36(1), 58-77.

Udipi, S. (2007). An investigation of the personal and demographic predictors of compassion fatigue among genetic counselors. ProQuest Information and Learning Company.

Uy, N. \& Hernandez, F. (2015). Personality traits and the predictor of compassion fatigue among Dominican counselors. The Guidance Journal (PGCA).

Valdez, D. (2018). Lack of registered guidance counselors forces schools to keep unlicensed ones. ABS-CBN news. Retrieved from http://news.abs-cbn.com/focus/01/14/18/lack-of-registered-guidance-counselors-forcesschools-to-keep-unlicensed-ones-part-1

Villar, I. V. (2007). Implementing a comprehensive guidance and counseling program in the Philippines. Aligned Transformations. 
Visger, V. (2016). The importance of self-care for helping professionals. Retrieved from https://allthingspossiblewc.com/the-importance-of-self-care-for-helping-professionals/

Vredenburgh, L. D., Carlozzi, A., \& Stein, L. (2007). Burnout in counseling psychologists: type of practice setting and pertinent demographics. Journal of Counselling Psychology Quarterly, 12. Retrieved from https://www.tandfonline.com/doi/abs/10.1080/09515079908254099?journalCode=ccpq20

Wells, B. (2008). Burnout and compassion fatigue in school counselors: a mixed method design. ProQuest LLC.

Whitbourne, S. (2017, July 11). Research suggests a cure for neuroticism. Psychology Today. Retrieved from https://www.psychologytoday.com/us/blog/fulfillment-any-age/201707/research-suggests-cureneuroticism

Wilkerson, K. (2009). An examination of burnout among counselors guided by stress-strain - coping theory. Journal of Counseling \& Development, 87, 428-437.

Wilkerson, K. \& Bellini, J. (2006). Intrapersonal and organizational factors associated with burnout among school counselors. Journal of Counseling and Development, 84, 440-450.

Woolley, A. W., Chabris, C. F., Pentland, A., Hashmi, N., \& Malone, T. W. (2010). Evidence for a collective intelligence factor in the performance of human groups. Science, 330, 686-688.

World Health Organization. (1998). WHOOQL user manual. Geneva, Switzerland: Author.

Yusi, L. (2018, September 3). Personal interview. 